\title{
Üç Testis Şikâyeti ile Gelen Hastada Paratestiküler Mikst Fibrosarkom
}

\section{Paratesticular Mixed Fibrosarcoma in a Patient Coming with Three Testicles}

\author{
Eser ÖRDEK $^{1}(\mathbb{D})$, ibrahim Halil ALBAYRAK ${ }^{1}(\mathbb{D})$, Bülent KATI ${ }^{1}(\mathbb{D})$, Halil çifTÇi ${ }^{1}$
}

${ }^{1}$ Harran Üniversitesi Tıp Fakültesi, Üroloji Anabilim Dalı, Şanlıurfa

Öz.

Paratestiküler liposarkomlar, skrotum içerisinde rastlanan nispeten yaygın sarkomlardır ancak miksoid varyantı çok nadir rastlandığı kabul edilir. Bu malign hastalığın seyrek olması sebebiyle standart bir tedavi protokolü mevcut değildir. Literatürde bu konu ile ilgili farklı sonuçları olan çeşitli tedaviler uygulanmıştır. Bu vakamızda fazladan testisi olma şikâyeti ile gelen hastada sol paratestiküler yumuşak dokudan köken alan bir miksoid liposarkom olgusunu sunmayı amaçladık.

Anahtar kelimeler: Paratestiküler sarkom, Yumuşak doku sarkomu, Liposarkom

\section{Abstract}

Paratesticular liposarcomas are relatively common sarcomas in the paratesticular region but the myxoid variant is considered very rare. There is no standard treatment protocol due to this malignant disease is rare. In the literature, various treatments have been applied with different results on this subject. In this case, we aimed to present a case of myxoid liposarcoma originating from the left paratesticular soft tissue in the patient who came with the complaint of having extra testes.

Keywords: Paratesticular sarcoma, Soft tissue sarcoma, Liposarcoma

\section{Sorumlu Yazar / \\ Corresponding Author}

Dr. Eser Ördek

Harran Üniversitesi Tıp Fakültesi

Üroloji Anabilim Dalı,

Osmanbey Kampüsü,

Haliliye / Şanlıurfa

E-mail: dr_eseser@hotmail.com

Geliş tarihi / Received:

06.05.2020

Kabul tarihi / Accepted:

14.07.2020

DOI: $10.35440 /$ hutfd.733233 


\section{Giriş}

Paratestiküler sarkomlar nadir görülmekle birlikte kesin orijinini tespit etmek zordur. Bununla beraber tümörlerin en sık spermatik korddan (\%90) kaynaklandığı düşünülmektedir (1). Ayrıca testiküler tunika katlarından veya epididimden köken alabilirler. Bu tümörleri önemli kılan özelliği yetersiz eksizyonun ardından yüksek lokal rekürrens potansiyeline sahip olmalarıdır. Bu vakada 69 yaşında erkek hastada sol paratestiküler yumuşak dokudan köken alan paratestiküler miksoid liposarkom olgusunu sunduk.

\section{Olgu Sunumu}

69 yaşında erkek hasta, bir ay önce fark ettiği sol skrotumunda ağrısız şişlik ve fazla testis şüphesi ile polikliniğimize başvurdu. Fizik muayenede sol testisten bağımsız, testisin superiorunda sert yapıda düzgün sınırlı yaklaşık 5 cm'lik bir kitle palpe edildi. İnguinal bölgede lenfadenopati palpe edilmedi. Yapılan skrotal doppler ultrasonografide sol spermatik kord distalinde $44 \times 27 \mathrm{~mm}$ boyutunda heterojen hiperekoik kitlesel lezyon izlendi. Bu kitle lezyonu içerisinde $2 \mathrm{~cm}$ çaplı heterojen hipoekoik oluşum rapor edildi. Hastanın hikayesinde herhangi bir travma ya da geçirilmiş ateşli hastalık yoktu. Bütün kan değerleri ve testis tümör markerları normaldi. Hastanın preoperatif çekilen tüm abdomen ve toraks görüntülemelerinde, metastaz veya lenfadenopati izlenmedi. Hastaya maliğnite şüphesi sebebiyle sol inguinal eksplorasyon yapılarak kitle normal testis dokusu ile birlikte komplet çıkarıldı (Resim 1).

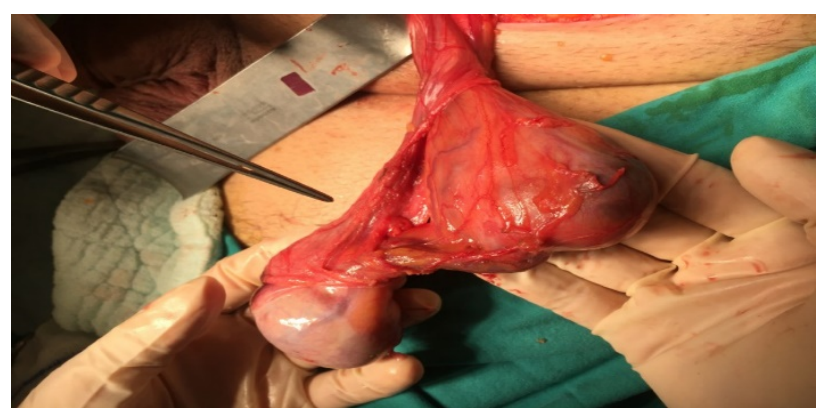

Resim 1. Skrotal ekspolorasyon sırasında gözlenen ekstra testis görünümlü oluşum

Spesmenin patolojik incelemesinde, testiküler ekstra oluşumun Malign Mezenkimal Neoplazisi olduğu ve histopatolojik bulguların "Miksofibrosarkom benzeri patern yapıları içeren liposarkom" ile uyumlu olduğu rapor edildi (Resim 2). Hastanın medikal onkoloji ile birlikte yapılan takiplerinde cerrahiden sonraki üç ve altı aylık kontrollerinde tümör nüksü veya metastaz bulgusu izlenmedi.

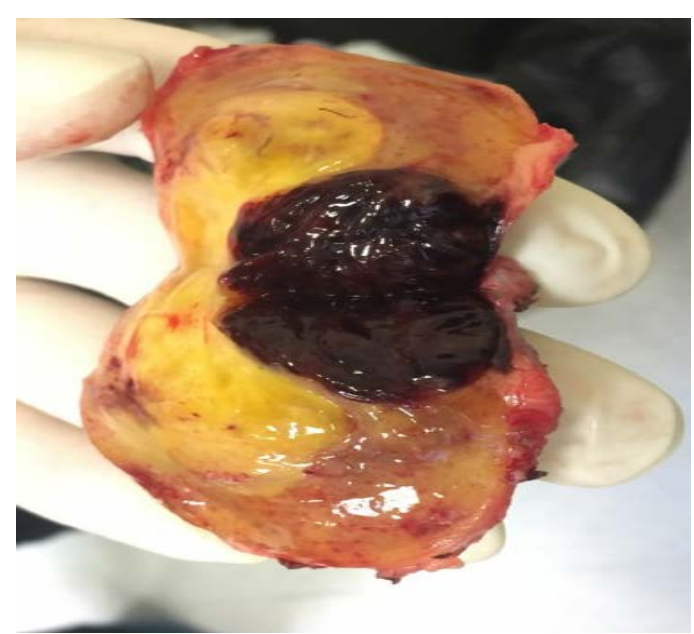

Resim 2. Kitlenin makroskopik iç yapısı.

\section{Tartışma}

Miksoid liposarkomlar, skrotal boşluğun çok nadir görülen bir tümörüdür. Bu anatomik bölgede liposarkomların yaklaşık \%3,3'ünü temsil eder (1). Genellikle orta yaş veya daha ileri yaşlardaki erkek hastalarda görülmektedir. Paratestiküler liposarkomların çoğu primerdir ancak bir kısmı femoral bölge veya testisleri çevreleyen yağ dokusu gibi diğer bölgelerdeki liposarkomların metastazı olabilir. Ele gelen bir skrotal veya inguinal kitle, hidrosel, germ hücreli tümörler, epididimal tümörler, skrotal lipoma, epididimit, orşit, epidermoid kist ve metastaz gibi benign veya maliğn hastalıklarla karıştırılan en yaygın bulgulardır (2). Genellikle ameliyat sonrası histopatolojik olarak tanı konulmaktadır. Lokal nüks yapmaları ara malign davranışından kaynaklanır. Çok nadir de olsa uzak organlara metastaz yapabilirler. Miksoid liposarkomlar için genel sağkalımı etkileyen çeşitli prognostik faktörler bildirilmiştir. Bunlar yuvarlak hücre bileşeninin yüzdesi, MIB-1 LI (MIB-1 labelling index), nekroz, mitoz ve tümör derecesidir (3).

Paratestiküler miksoid liposarkom için altın standart bir tedavi yöntemi bulunmamaktadır. Buna rağmen çevre yumuşak dokuların geniş lokal eksizyonu ve spermatik kordun yüksek ligasyonu ile radikal orşiektomi, bu hastalığın tedavisinde en iyi sonuçları veren cerrahi tedavi yöntemidir (4). Bu şekilde inkomplet rezeksiyon ile ilişkili meydana gelebilecek nüks riski minimize edilmiş olur. Genel kabul gören orşiektomi yöntemi inguinal insizyondur. Bununla birlikte bu hastalarda rutin olarak metastaz dışında retroperitoneal lenf nodu diseksiyonu önerilmemektedir (5). Kemoterapi tedavisine kısmen dirençli olmaları sebebiyle, miksoid liposarkomda rutin adjuvan 
sistemik tedavi endikasyonu yoktur. Tümör rekürrensinin yeterli tedavisi, daha önce yapılmadığı takdirde, sıklıkla radikal orşiektomi ile geniş inguinal lenf nodu rezeksiyonunu içerir. Ancak tam tümör eksizyonu yapılamıyorsa, adjuvan radyoterapi lokal rekürrens oranını belirgin olarak azaltabilir (6). Büyük organların veya kan damarlarının invazyonuna sekonder cerrahi rezeksiyonun mümkün olmadığı durumlarda tek tedavi olarak radyoterapi önerilir (6). Miksoid liposarkom, tüm alt tiplerin en radyosensitifidir (7).

Sonuç olarak, miksoid liposarkom için ameliyat öncesi tanı konulmasında zorluklar yaşanabilmektedir. Önceden tanı konulmuş veya yüksek şüphe uyandırmış ise geniş lokal eksizyon ve yüksek ligasyon ile radikal orşiektomi en iyi tedavi yöntemidir. Lokal nüks ve uzak metastaz riski nedeniyle miksoid liposarkom hastalarında uzun dönemli onkolojik takibi önerilir.

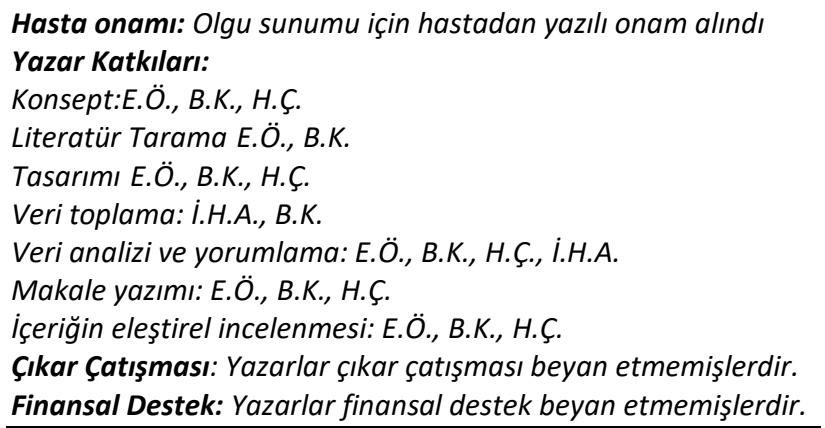

\section{Kaynaklar}

1. Khoubehi B, Mishra V, Ali M, Motiwala H, Karim O. Adult paratesticular tumours. BJU Int 2002;90:707-15.

2. Fitzgerald S, MacLennan GT. Paratesticular liposacroma. J Urol. 2009;181:331-32.

3. Tateishi U, Hasegawa T, Beppu Y, Kawai A, Moriyama N. Prognostic significance ofgrading (MIB-1 system) in patients with myxoid liposarcoma. J Clin Pathol. 2003;56:579-82.

4. Mondaini Palli D, Saieva C. Clinical characteristics and overall survival in adultgenitourinary sarcomas treated with a curative intent: a multicenter study. Eur Urol. 2004;47 468-73.

5. Li F, Tian R, Yin C. Liposarcoma of the spermatic cord mimicking a left inguinal hernia: a case report and literature review. World J Surg Oncol. 2013;11:18.

6. Bauer JJ, Sesterhenn IA, Costabile RA. Myxoid liposarcoma of the scrotal wall. J Urol. 1995;153 1938-39.

7. Lissmer L, Kaneti J, Klain J, Peiser J, Maor E, Cohen Y. Liposarcoma of the perineum and scrotum. Int Urol Nephrol. 1992;24(2):205-10. 